\title{
Bone marrow transplantation from the donors' perspective - a contribution to research in the field of health pedagogy
}

\author{
Karol Moty ${ }^{1}$ \\ ${ }^{1}$ Faculty of Social Sciences, Jan Dlugosz University in Czestochowa, Poland
}

HOW TO CITE:

Motyl, K. (2021).

Bone marrow transplantation from the donors' perspective

- a contribution to research in the field of health pedagogy.

International Journal

of Special Education, 36(2), 36-43

CORRESPONDING AUTHOR:

Karol Motyl;

k.motyl@ujd.edu.pl

DOI:

https://doi.org/10.52291/ijse.2021.36.16

COPYRIGHT STATEMENT:

Copyright: (C) 2021 Authors.

Open access publication under the terms and conditions

of the Creative Commons

Attribution (CC BY)

license (http://creativecommons.

org/licenses/by/4.0/).

\begin{abstract}
:
The article presents a research objective relevant to the subject matter of bone marrow transplantation. This study aimed at providing the rationale for locating the designed research in the field of health pedagogy. Such 'assigning a research identity to this project will assist in perfecting it even further. The subject matter undertaken in this article is relevant to the actual experiences of bone marrow donors from the period of undergoing the procedure of transplantation. This subject matter seems to be constituting a terra incognita from the point of view of scientific research, and this supposition is confirmed by the conducted library and sources search. The author attempts to refer, in a succinct form, to certain theoretical conceptions and methodological approaches, which may be used within the frameworks of exploring the thus-defined field of research. The final part of this text is composed of brief comments made by actual bone marrow donors and relevant to their experiences. These comments constitute a sui generis recapitulation of, and a rationale for, the need to conduct the research described in this article.
\end{abstract}

Keywords: bone marrow donor; experience; transplantation; health pedagogy. 


\section{INTRODUCTION}

Ever since blood has been regarded as the source of strength and life. It was already Hippocrates that claimed that it is one of the humours exerting influence upon the temperament of a particular individual, whereas Galen discovered that the veins and aortas transport this same tissue throughout the organism. Describing blood circulation by William Harvey in the year 1616 provided foundations for the intravenous administration of substances intended to improve the state of health of a patient, and discovering blood groups by Landsteiner in the year 1900 marked the beginning of the development of contemporary transfusion medicine. A further milestone was reached when the technique of bone marrow biopsy was developed. It ought to be emphasised that the first attempts to transplant bone marrow in Poland (and probably also worldwide) were made in the year 1938 by Jan Rosenbusch at the Clinic of Paediatrics of the Jan Kazimierz University in Lviv. Owing to several decades of the development of research into bone marrow transplantation, and a regular increase in the number of the performed procedures of transplantation, it has been possible to save the lives of thousands (Machowicz, 2014).

Bone marrow transplantation is applied in the treatment of blood disorders (both neoplastic and non-neoplastic). Owing to it, it is possible to reconstruct the haematopoietic system which is not functioning properly, or which has been destroyed. It is possible to transplant cells from a donor who is (or is not) a relative of the recipient, or the mother cells from the patient (Procedura transplantacji..., 2021).

In Poland, every 40 minutes an individual is informed that they suffer from a blood neoplasm. Unfortunately, only $25 \%$ of the patients find a compatible donor in their family $(75 \%$ of the patients need transplantation from a donor who is not their relative). Despite that fact, the number of registered potential bone marrow donors in the database of the DKMS (Polish acronym for Blood Marrow Mother Cell Donors) Foundation ${ }^{1}$ in Poland amounts to $1,777,922$, and, still, every fifth individual in need fails to find an individual with sufficiently similar genes. Of all potential donors, only 9,013 have been able to donate their bone marrow. Thanks to bone marrow donors, an ever-larger number of patients have a chance to stay alive, therefore, it is so important both for patients and for the development of transplantology that more and more people register as donors $(1,7 \mathrm{mln}$ zarejestrowanych..., 2021).
According to statistical data, every single day four Polish donors from the database of the DKMS Foundation donate haematopoietic mother cells to patients in the need of transplantation (Dlaczego Dawcy..., 2021). From the point of view of the statistical data quoted earlier in this article, this is still a small number. The factor slowing down the registration of new donors is the lack of reliable information about bone marrow transplantation. That, in turn, gives birth to myths relevant to the procedure of donating bone marrow, which causes anxiety and, not infrequently, fear of a danger to health (and frequently to life), and also of that of pain, and keeps these very myths alive.

From the perspective of the research objective described in this article, transplantations from a donor not being a relative of a recipient, in the case of which the procedure of transplantation is preceded by a process of qualification, are conducted in a centre of transplantology, will be significant. The process of the qualification itself and examination, as well as the biopsy of bone marrow and the course of action after the procedure, may contribute to various experiences in the case of actual donors, who may understand these very experiences in a number of ways. Collecting and describing these experiences, and also an attempt to assign meanings to them is the most general objective of the research described in this article, which, in the further perspective, aims to acquire and convey a reliable knowledge on donating bone marrow.

I would like to indicate that this idea is a recent one, remaining in statu nascendi, and that it involves a number of questions that still need answers and dilemmas that have not been resolved, and of the existence of which I am fully aware of. This text is treated by me as an attempt to locate research into the idea of bone marrow donorship as a subject matter significant from the point of view of pedagogical sciences.

As I have mentioned before, the narrations of actual bone marrow donors may contribute not only to broadening knowledge about conducting transplantations but also to changing behaviours and attitudes relevant to caring and feeling responsible for health, understood as an individual and social value. Developing the conception relevant to this subject matter was preceded by reviewing research in the field of transplantations / donating bone marrow. Upon the basis of it, I can find this area to be a terra incognito in social sciences. After making myself acquainted with Polish and foreign Internet scientific databases (eg. EBSCO, SCOPUS, Google Scholar) and repositories (eg. Jagiellonian University Repository, 
Adam Mickiewicz University Repository, University of Warsaw Repository, Knowledge Base of the University of Gdańsk), I can differentiate the groups of subject-matters referred to below and relevant to research in the field of bone marrow transplantation in the aspect of social sciences:

- the knowledge and attitudes of students and secondary school attendees on the issue of bone marrow transplantation;

- the attitude of students to activities promoting health as exemplified by an informational-education campaign relevant to donating bone marrow;

- the attitudes of the parents after bone marrow transplantation;

- bone marrow donorship as a selfless behaviour; the attitude and motivation of individuals expressing their willingness to donate bone marrow; motivation and satisfaction in the process of donating haematopoietic cells;

- the history of transplanting bone marrow and haematopoietic cells.

Not a single one of the scientific texts (from various countries written in English and Polish) in the databases searched by me was relevant to the experiences of bone marrow donors, but rather only to their health, biological functions, the side-effects of the procedure, motivation, attitudes, selflessness and satisfaction. Therefore, it is possible to presume that the research proposed under my project is, to a degree, innovative and may fill in a gap in research and complement relevant knowledge existing at the moment.

\section{LOCATION IN DISCIPLINE}

The subject matter of the idea of donorship and bone marrow transplantation seems to be a multi-dimensional and multi-faceted one. There is no doubt that the logical choice of the discipline of science to analyse this subject matter is medical sciences and health sciences. Attempts to explore the field of research which is constituted by the categories of health and illness are made in the field of philosophy (Carel, 2016), sociology (Shilling, 2010) or psychology (Taylor, 2018) as well. Within the scope of educational sciences, the above-mentioned notions are analysed by health pedagogy, which, as a subdiscipline of pedagogy, was initiated in the 1970s. It is understood as the theory of educative intervention in the life and the health of a human being. It constitutes a theoretical and methodological foundation for health education, and its interests are concentrated upon edu- cational processes (of upbringing and instructing), the essence of which is to develop personal predispositions of a human being by conveying knowledge and skills, by shaping the system of values, attitudes, and also behaviours connected with health (Woynarowska, 2007). Health pedagogy analyses such issues as the social-environmental determinants of health and illness, multi-aspect activities (among others, education, diagnosing, designing changes, compensating and social work), activities in the environment (undertaken within/by institutions and not) to benefit the health of various social groups, the process of education and upbringing the intended outcome of it is to improve health (physical, mental and social) and improve real-life skills conducive to a healthy lifestyle and improving the quality of it in every single period of human life (Tuszyńska, 2015). Health education strives to provide knowledge as well as the requisite skills necessary to apply that knowledge - while developing appropriate attitudes - to result in healthy behavior choices or behavior changes as needed (Gilbert at al., 2011).

Health pedagogy is a relatively new notion in the literature because it is much more frequently possible to come across such terms as health education, education for health, sanitary education and hygienic education (Charońska, 2008). "Another problem is the fact that health pedagogy must defend its status of an autonomous and separate discipline of science all the time. Health education has functioned as a separate discipline for approximately the last 30 to 60 years and ss a relatively new discipline, it has always struggled for a strong sense of identity" (Gilbert at al., 2011). Pizon (2019, p. X) wrote, that "this field of research inherently calls for multidisciplinarity. It is almost amusing that this field of research that remained marginal for several years has now found its place, notably in university disciplines where it was not expected nor wanted. However, we will retain from this evolution the positive character generated by this gradual movement of multidisciplinary appropriation". Despite these problems, health education continues to evolve into an important discipline with a unique orientation to addressing the health education needs of the world (Gilbert at al., 2011).

Health pedagogy concentrates, first and foremost, upon highlighting connections between human health and their lifestyle, and also the environment: both physical and social, upon highlighting the problems of health, and also personal decisions and social activities within the scope of pro-health behaviours (Charońska, 
2008). "Health education is the discipline that deals with facilitation of modifying health behaviors. Health education has been defined in several ways (Sharma $\&$ Romas, 2008). It can be referred to as a communication activity aimed at enhancing positive health and preventing or diminishing ill-health in individuals and groups through influencing the beliefs, attitudes and behavior of those with power and the community at large" (Downie at al., 1990, p. 28). It also may be described as any planned combination of learning experiences designed to predispose, enable, and reinforce voluntary behavior conducive to health in individuals, groups, or communities (Green \& Kreuter, 2005).

In health pedagogy, it is possible to differentiate between two aspects. The first one of them is health pedagogy, the object of interest of which is research into the influence exerted by an individual's health (and that of groups, too) upon the processes of upbringing and education. The other one is a pedagogy for health, the function of which is to support pro-health activities by means of enriching knowledge and a set of tools available for the purpose of the promotion of health (Szewczyk, 2006). A researcher working in the field of health pedagogy ought to be dedicated to their work. "Linking education and health pushes the researcher in his entrenchment, sends him back to his role as a citizen, to what he is himself. Describing these links jostles him in terms of his personal and professional history" (Pizon, 2019, p. XI). Concerning this aspect, what ought to be indicated is, connected with health pedagogy, the interdisciplinary area of research activity, constituted by narrative medicine.

Narrative medicine, also known as illness narrative, is the conception of relations with a fellow human being, in which a major aspect is constituted by appreciating the role of the narrations of individual patients in the therapeutic process. Listening to the stories told by patients, one attempts to understand and interpret them so that one could offer holistic care both best and most adjusted to their needs. Owing to that, it is possible to bridge the gap between the two separate areas of experiences: the world of the treated individual and the world of the treating individual. Narration renders it possible for the people involved in medical care to understand the experiences, pain and suffering of patients. Only when there is a dialogue and a truly interpersonal contact between those involved on both sides, is an actual understanding possible. Narrative medicine follows three principles: concentration upon listening to the words of a patient, and also observing their non-verbal behaviour, presenting the outcomes of a conversation with a patient either in the form of an entry into the case history or in the form of a note made by a professional (reflective writing), developing a bond between participants in the relation, which consists in mutual understanding. The presumption behind narrative medicine is, first and foremost, listening to the narrations of patients presenting a biographical and social context of their illness, and also the strategies of coping with it. Another form of narration is that of an expert, which is constituted by professionals' descriptions of their relations with patients, also reactions to their behaviour. Narration may also assume the form of a co-created narration set in the context of the narration of a patient and a doctor. The most global form of narration is meta-narration connected with the context of the health and illness of particular social groups (Kalitzkus \& Matthiessen, 2009; Charon, 2011; Shapiro, 2011; Shapiro, 2012; Zurzycka \& Radzik, 2015).

Mladic discourse is connected with narrative medicine; this discourse is understood as a sum of social contexts and meanings constructed around the notion of an illness, and constituting a register of emotions, impressions, moods, fears and anxieties connected with an illness and the experience of it, both real and potential, both one's own and that of other people. At this point, it ought to be indicated that it is not possible to take the burden of another individual's suffering upon oneself because pain and illness can never be given to anyone else, or translated into the language of another individual's experiences. The essence of this discourse is a multi-aspect and comprehensive reflection relevant to an illness understood from the level of different research orientations, taking under consideration opinions voiced by people representing different points of view; anxiety and state of tensions are the foundations of this discourse, and they are both connected with fragility and vulnerability of a human body (Szubert, 2019).

Invoking the words of Demel (1980), who was a founder of the Polish school of health education and a modern concept of physical education, I adopt the presumption that health education is a part and parcel of shaping personality to the full, and that consists, among others, in stimulating a positive interest in the matters of health by episodic and methodical enriching and deepening knowledge about oneself, as well as about the principles governing public health. In this aspect (and upon the basis of previous findings), it ought to be stated that the described research objective is in 
the field of health pedagogy as a pedagogical subdiscipline. That decision may be justified by scientific ambition to popularise the idea of bone marrow donorship, resulting in the stimulation of interest in the matters of health, and also enriching and deepening knowledge about oneself, as well as about the principles governing public health.

In my opinion, the described idea for research integrates two pedagogical subdisciplines: health pedagogy and special pedagogy. When analyzing the concept of health and disease, I refer to a man who requires support and help in overcoming various difficulties. On the one hand, he is a cancer patient who requires care and understanding - the perspective of special education. On the other hand, there is a donor who helps in recovery and who also needs support during the transplantation and in the field of promoting the idea of bone marrow donation - the perspective of health pedagogy.

\section{THEORIES AND METHODS}

The subject matter of the planned research will be experiencing the process of bone marrow transplantation by actual donors. The initial exploration of this field of research will aim at determining basic categories, processes or phenomena, connected with experiencing donation, and these, in turn, will be indispensable for designing a broader scope of research. The results of the designed research ought to guide the next still planned scientific undertakings within this scope.

Exploring the thus-defined field of research may involve the presumption of conducting theoretical exploratory research. The subject matter of research determined hereinabove indicates the adoption of the interpretative paradigm, emphasising that social facts are ascribed individual and subjective meanings, and indicating human will as a causative power behind human actions. Therefore, the reason for changes occurring in a human being is this very human being as an active participant, practically involved in their life, and the elements of the surrounding world exert influence upon them, but rather have their meanings (Kacprzak-Wachniew, 2020). The attention of a researcher remains concentrated upon the subjective experiences of human beings, the manners of acquiring awareness within the frameworks of social structures and negotiating the meaning. This approach presumes that what is important for the studied individuals ought to be understood (Urbaniak-Zając, 2013).

In order to conduct the initial analysis of the process of bone marrow donorship, it is planned to use the theory of the rite of passage as presented by van Gennep (2006) and also Turner (2010). The procedure of donating bone marrow itself will be understood as a sui generis process of a change in the status of a donor from potential (an individual registered in the database of donors) to an actual one. In that case, three phases may be differentiated: preliminary (from registration in the database to receive a phone call with information that a recipient has been found), liminal (from receiving a phone call with information that a donor has been found, to a medical and administrative procedure to the procedure of bone marrow transplantation), post-liminal (since the procedure of bone marrow transplantation to receiving the first phone call with information about the state of health of a recipient). V. Turner emphasised the potential of a liminal state as a critical, pivotal moment, as a state of cultural deconstruction, in the course of which much may occur. The rite of passage, by providing the possibility to create liminal experiences, becomes a category of the analysis of different phenomena (Jaskulska, 2018).

A certain temporal dimension results from thus-perceived participation in the procedure of transplantation. In research into the experiences of the actual donors of bone marrow, there are three temporal perspectives: relevant to the experiences preceding the biopsy, relevant to experiences in the period of the procedure of biopsy, and relevant to experiences following donation. The consequence of that may be using the appropriate research method, namely the biographical method. In this aspect, the construct in use may be Fritz Schütze's conception of the processual structures of the life course, in which the following elements may be differentiated: institutional models, biographical patterns, activities, metamorphoses, and also trajectories (Rokuszewska-Pawełek, 2006; Schütze, 1981).

Referring to the technique of collecting data, it seems that it is appropriate to apply narrative interview (the principal advantage of it is that the study conducts the processual reconstruction of the experiences, and also the possibility of combining in a narration three temporal perspectives: past, present and, to a degree, future as well; presenting those three perspectives, and also their mutual relations, will render it possible to analyse the experiences of the process of bone marrow donation by the studied individuals (Lalak, 2010).

It is proposed that, in the project, the non-probability sampling of a research sample be adopted. In order to maintain the homogeneous profile of the group, I formulated a single criterion of selection, and that means having a status of an actual bone marrow donor. The 
studied individuals are the Members of the Donor Club of the DKMS Foundation, which can boast approximately 1,500 individuals as members. The donors being the members of the Club meet no less frequently than once a year (remotely since the beginning of the pandemics), remain in real contact and initiate, and also organise, numerous undertakings promoting the idea of bone marrow donorship. Participation in my research has already been declared by more than a dozen of actual donors, and the DKMS Foundation proposed that it would act as the patron of the project.

\section{INSTEAD OF CONCLUSIONS AND DISCUSSION}

Pursuing the idea of the research project described hereinabove, which was at that time taking shape, I contacted the DKMS Foundation, which reacted with enthusiasm to the undertaking planned by me. I was assured that the Foundation would support me in implementing this scientific project and that promoting research connected with bone marrow transplantation is one of its statutory activities. My idea was forwarded to 'The Donor Club of the DKMS Foundation'. The comments relevant to my project, and being answers to the question 'What changed in my life [after donating bone marrow]?' were numerous. Hereinbelow, I include several examples of the comments (keeping original spelling unchanged):

Much has changed in my life perhaps, not as much as in terms of what I possess, but rather in those of ethics and spiritual life. I think I'm a better man now.

It has changed. My whole life, I mean. And now I think more about other people, ill people. And how I can help them. Every life is a different story, both of the donors and recipients, read by me. I started to donate blood. To enjoy every single moment.

Not too much has changed in my life. I think that a surge of compassion such as donating a part of oneself to a fellow human being ought to be natural, and does not need to evoke emotions or trigger spiritual transformations $(\ldots)$

Many perceive donors as silent heroes, but there's another side of the coin, too. It is worth sparing a thought to the question, whether, perchance, a recipient does not save our life, too. Sometimes, we struggle with hardships which can be a step from becoming a straw able to break the camel's back. By finding an individual who needs us to stay alive makes our own life more meaningful, too. Such a situation may enable a donor to 'shuffle off this deadly coil of marasmus', as William Shakespeare might have expressed it, as they become important to someone, and their life acquires an additional dimension. I donated bone marrow at a very difficult moment of my life (perhaps, the hardest so far). It helped me bounce back, which I'm grateful for.

The words: 'If you give a good thing to the world, then over time your karma will be good, and you'll receive good' proved true in my case!

I make people aware that I helped because I had wanted to help. Not for pictures. Not for likes. I repeat all the time that, for someone to be able to boast of being a donor, someone else must develop an illness, and the healthy cannot understand the illness.

In my case, donating cells helped to deal with mom's death. She died of cancer in my arms and, for years, I had had the pangs of conscience that I hadn't helped her. Becoming a donor was a bit like therapy. I couldn't save my mom, but for the mom of someone else, I did what I could. And, of course, my self-assessment improved. Whatever you say, I know now I did something f....g important in my life!

It is me who has been taught to help ever since. Frankly speaking, nothing has changed. My attitude to it is, perhaps, a little bit different, but if it changed someone else's viewpoint on life at least now, then it is only fine it did.

Much has changed in me. My way of thinking. Every single day brings joy now and after seeing the movie ŻYCIE NR 2 (Life No.2) I got so much emotional that even the triflest thing make me merry.

The above opinions do not reflect the potential richness and complexity that are hidden in the experiences of bone marrow donors. However, the comments are a good exemplification of some aspects of the research concept described in this text. The emerging categories of morality, responsibility, spirituality, changes, transformations, good, help, everyday life, on the one hand, justify the need for the research described in this way. On the other hand, show a wide range of possibilities for scientific exploring of experiences of bone marrow donors. 


\section{ACKNOWLEDGMENTS}

This paper would not have been possible without the exceptional support of Members of National Doctoral and Habilitation Seminar organized at the University of Lodz and Participants of Young Pedagogists' Summer School. Their enthusiasm, knowledge and exacting attention to detail have been an inspiration to write this paper.

\section{DISCLOSURE STATEMENT}

No potential conflict of interest was reported by the authors.

\section{FUNDING}

None.

${ }^{1}$ DKMS is an international charity dedicated to the fight against blood cancer and blood disorders and involve in medical science. Its mission is to find a donor for every patient who needs a bone marrow stem cell transplant.

${ }^{2}$ A group operating at the DKMS Foundation, dedicated to actual bone marrow donors. Its aim is to support actual donors, exchange ideas and experiences, and initiate joint activities to spread the idea of bone marrow donation.

\section{REFERENCES}

1,7 mln zarejestrowanych dawców szpiku, to za mało. (2021). DKMS. https://www.dkms.pl/o-pobraniu/szukanie-dawcy/1-7-mln-zarejestrowanych-dawcow-szpiku-to-za-malo, [dostęp: 26.09.2021].

Carel, H. (2016). The philosophical role of illness [in:] Phenomenology od illness. Oxford University Press.

Charon, R. (2011). The novelization of the body, or how medicine stories need one another. Narrative, 19(1), 36-38.

Charońska,E. (2008). Podstawy teoretyczne edukacji zdrowotnej [in:] Promocja zdrowia. Tom I, (ed.) A. Andruszkiewicz, M. Banaszkiewicz. Czelej.

Demel, M. (1980). Pedagogika zdrowia. WSiP.

Dlaczego Dawcy wycofują się z procedury oddania szpiku? (2021). DKMS. https://www.dkms.pl/dawka-wiedzy/o-rejestracji/ dlaczego-dawcy-wycofuja-sie-z-procedury-oddania-szpiku, [dostęp: 26.09.2021].

Downie, R., Fyfe, C., Tannahill, A. (1990). Health promotion: Models and values. Oxford University Press.

Gilbert, G., Sawyer, R., McNeill, E. (2011). Health Education: Creating Strategies for School and Community Health. Jones and Bartlett Publishers.

Green, L. W., Kreuter, M. W. (2005). Health program planning. An educational and ecological approach. McGraw Hill.

Jaskulska, S. (2018). Rytuał przejścia. Młodzież szkolna na progu edukacyjnym. Wydawnictwo Naukowe UAM.

Kacprzak-Wachniew, K. (2020). Sensy i znaczenia nadawane przez adolescentki ich doświadczeniom bycia w związkach uczuciowych, UKW.

Kalitzkus, V., Matthiessen P. (2009). Narrative-based medicine: potential, pitfalls, and practice. The Permanente Journal, 13(1), 80-86. https://doi.org/10.7812/TPP/08-043

Lalak, D. (2010). Życie jako biografia. Podejście biograficzne w perspektywie pedagogicznej. ŻAK.

Machowicz, R. (2014). Historia przeszczepiania szpiku w Polsce. Nowotwory. Journal of Oncology, 64(5). 460-465. https://doi. org/10.5603/NJO.2014.0075.

Pizon F. (2019). Health Education and Prevention. Wiley

Procedura transplantacji komórek macierzystych. (2021). DKMS. https://www.dkms.pl/dawka-wiedzy/o-nowotworach-krwi/procedura-transplantacji-komorek-macierzystych [dostęp: 25.03.2021]. 
Rokuszewska-Pawełek, A. (2006). Wywiad narracyjny jako źródło informacji. Media, Kultura, Społeczeństwo, 1, 17-28.

Schütze, F. (1981). Prozessstrukturen des Lebensablaufs, [in:] Biographie in handlungswissenschaftlicher Perspektive, Verlag der Nürnberger Forschungsvereinigung. (ed.) J. Mathes. Nürnberg.

Shapiro, J. (2011). Illness narratives: reliability, authenticity and the empathic witness. Medical Humanities, 37(2), 68-72. http:// dx.doi.org/10.1136/jmh.2011.007328

Shapiro, J. (2012). Narrative medicine and narrative writing. Family Medicine, 44(5), 309-311.

Sharma, M., Romas, J. (2008). Theoretical Foundations of Health Education and Health Promotion. Jones and Bartlett Publishers.

Shilling, C. (2010). Socjologia ciała. PWN.

Szewczyk, T. (2006). Pedagogika zdrowia [in:] Pedagogika. Tom 3, (ed.) B. Śliwerski. GWP.

Szubert, M. (2019). Dyskurs maladyczny - perspektywy badawcze [in:] Fragmenty dyskursu maladycznego. tom 1. (ed.) M. Ganczar, I. Gielata, M. Ładoń. Fundacja Terytoria Książki.

Taylor, S., E. (2018). Health psychology. University of California. McGraw-Hill Education.

Turner, V. W. (2010). Proces rytualny. Struktura i antystruktura. PIW.

Tuszyńska, L. (2015). Zdrowie w dyskursie pedagogicznym. Polish Journal of Continuing Education, 2, 18-25.

Urbaniak-Zająć, D. (2013). Jakościowa orientacja w badaniach pedagogicznych [in:] Badania jakościowe w pedagogice. Wywiad narracyjny i obiektywna hermeneutyka. (ed.) D. Urbaniak-Zając, E. Kos, PWN.

Van Gennep, A. (2006). Obrzędy przejścia. Systematyczne studium ceremonii. PIW.

Woynarowska, B. (2007). Edukacja zdrowotna. PWN.

Zarzucka, P, Radzik, T. (2015). Medycyna narracyjna - zarys problematyki. Problemy pielegniarstwa, 23(3), 428-432. 